\title{
The system of human resource development in energy saving in the Ural region
}

\author{
V. U. Baldin, N. I. Danilov \& G. I. Khudyakova \\ Ural Federal University, Russia
}

\begin{abstract}
A system of education in the field of energy saving has been developed, built and successfully used for a number of years in the Ural region. In the Ural Federal University (UrFU) the "Energy Saving" Department and Regional Learning and Teaching Centre were created in 1999. At the present time more than 2000 senior students of ten institutes and of a number of UrFU territorial branches listen to lectures and study energy saving and energy efficiency issues at the practical studies yearly at the "Energy Saving" Department. In teaching the above mentioned disciplines a problematic-topical approach is used. It promotes forming a high level of concern and motivation among students to study and master the bases of theoretical and practical activity, enabling them to get the most actual and reliable information. Employees of the department have prepared and published a considerable volume of courseware and scientific-andtechnological literature on the problems of energy saving and raising efficiency of energy usage, forming an academic system, which includes different levels and types of knowledge, methods of educating. Masters' preparing has been started together with the department "Atomic power stations and renewable energy sources" with the deepened studying energy saving and energy efficiency issues. Taking this experience into account, an education standard of UrFU "Energy saving and energy efficiency raising in industry and budget sphere". Thus, a complex approach for creating and constantly improving the system of energy saving specialists' preparation has been realized and is being developed in the territory of the Ural region.

Keywords: system of education, energy saving, energy efficiency raising in industry and budget sphere, different levels and types of knowledge, methods of educating, courseware and scientific-and-technological literature, masters' preparing, Ural region.
\end{abstract}




\section{Introduction}

A system of education in the field of energy saving has been developed, built and successfully used for a number of years in the Ural region (the centre is Ekaterinburg). Critical need in such a system was expressed in Sverdlovsk region Governor E. E. Rossel's decree “About preparing specialists in energy saving for the organisations of the Sverdlovsk region", issued in February 1999. Thus wise in 1999 in the Ural State Technical University - UPI (nowadays Ural Federal University) "Energy Saving" Department and Regional Learning and Teaching Centre for preparing and certifying specialists in the field of energy saving were created.

\section{Different levels and types of knowledge system of education}

Since then employees of the department have developed study disciplines programmes, prepared and published study guides:

- for younger schoolers and preschoolers - "Energy saving for beginners" [1];

- for pupils of general academic schools, gymnasiums, lyceums, training schools and technicums (technical schools) - "Introduction in energy saving" [2], "Using resources and energy" [3];

- for students of technical, architectural-building and professionalpedagogical higher educational establishments - "Fundamentals of energy saving", "Energy audit and energy saving", "Small-scale power generation", "Energy saving technologies", "Theoretical bases of energy- and resource saving", "Information technologies and control systems in resource saving" and others;

- for teaching and professional development of specialists of enterprises and organisations of different profile - different level programmes of complex precertification preparation and forming knowledge, competences and skills in the sphere of energy saving, raising energy efficiency and carrying out energy inspections.

At the present time more than 2000 senior students listen to the lectures and study the energy saving and energy efficiency raising issues at the practical studies yearly at the "Energy saving" department. During these years more than 20000 senior students of ten institutes (faculties) and a number of the UrFU territorial branches have received training, this list continues to enlarge.

A report on this topic was made at the International symposium EURO-ECO 2013, organized by the European scientific society on the 28.11-29.11.2013 in Hannover, Germany [4].

\section{Methods of educating, courseware and scientific-and- technological literature, results of training and their usage}

In teaching the above mentioned disciplines a problematic-topical approach is used: professors and highly qualified specialists of the region professionally 
involved into the energy- and resource saving issues deliver lectures to students and listeners of professional development courses. It promotes forming a high level of concernment and motivation among students and listeners to study and master the bases of theoretical and practical activity in the given field, enables them to get the most actual and reliable information.

Employees of the department have prepared and published a considerable volume of courseware and scientific-and-technological literature on the problems of energy saving and raising efficiency of energy usage, forming an academic system, which includes different levels and types of knowledge, methods of educating: from preschool and household to professional and scientific, from popular to encyclopedic manuals, from classic paper textbooks to electronic interactive guides and multimedia courseware complexes.

In the period from 2000-2013 the department has prepared and published more than 120 study guides and resource books, which includes: 45 teaching aids, 25 academic learning aids, more than 50 reference books, monographs, encyclopedias. In 2008 a textbook "Fundamentals of energy saving" with the volume of more than 38 printed pages, with the number of (printed) copies more than 3100 was issued jointly with state-financed institution of Sverdlovsk region "Institute of energy saving" [5]. This is the first in the country textbook of such volume and coverage of topics. Representatives of many regional and Russia's organizations are interested in this edition. In this way in 2009-2011 with the support of CES-Holding, Ural Interregional High Voltage Grid Company and Sverdlovsk energy and gas company a textbook "Fundamentals of energy saving" was issued for the employees of these organizations with the total number of printed copies more than 3000 [6]. In 2012 an electronic version of the textbook jointly with the Institute of professional development of high-level personnel and specialists of Fuel and Energy Complex of RF Ministry of Energy was created, which is used in the system of personnel development system of not only Fuel and Energy Complex of the country, but also budget sphere.

Based on the results of scientific and research work the department has published more than 1200 scientific works during these period. Two dissertations of Doctors of Economics and two dissertations of Candidates of engineering sciences have been defended. Department works have become widely used in preparing documents in energy saving and raising efficiency of energy usage of Sverdlovsk region Government and also RF legislative acts, International Financial Corporation (IFC) recommendations (2010) [7], and UN reports (2009-2010) [8].

In the system of preparing and certifying specialists there have been trained and certified more than 6000 employees of the budget sphere, industrial enterprises, agriculture, building complex, housing and utility sector, defense and law enforcement agencies, municipal officers. The experience of this work has been presented in a resource book issued with the support of Ural Energy Service Company, Ural Interregional High Voltage Grid Company and Self-regulating organization - Noncommercial partnership "Union "Energy efficiency" [9].

A new perspective direction of educational activity of the department is organization and carrying out in 2007-2010 the preparation of specialists for 
region's administrative districts within the framework of state order "Educational services for professional development of Sverdlovsk region civil officers and municipal officers in Sverdlovsk region in energy saving issues" using videoconference conducting method. Lecture classes for this category of employees were conducted in the specialized premises of Department for methodological work in the Sverdlovsk region government building. Demonstrational video sequence was broadcasted to the centres of region's administrative districts, remote for dozens and hundreds of kilometres from Ekaterinburg, where there were listeners having an opportunity of direct interactive communication with a teacher during classes.

Such a method of teaching on the one hand requires teachers' thorough versatile preparation and high qualification and is going to be improved and on the other hand, at that broad opportunities open up to cover much larger and remote audiences of listeners to be educated, taking into account possibilities of already mastered technologies and fast developing communicational resources in our region.

Preparation of specialists is carried out in the volume not less than 80 academic hours. Study programmes have been developed and tested in practice for power engineering specialists of budget sphere and housing and communal services; for industrial enterprises of different branches: metallurgical, chemical, machine-building, mining taking into account specific character of sectoral technologies. Based on the results of these classes an electronic study guide "Organising energy saving work in Sverdlovsk region municipal entities" has been prepared and issued for the interested users, posted on the official website of the Sverdlovsk region government [10].

One should also point out the unique long-term experience of organizing and conducting all-Russian students' academic olympics on disciplines "Energy- and resource saving", "Unconventional and renewable power sources", scientificpractical conferences with international participation, exhibitions of scientifictechnical creative work of students, post-graduates and young scientists "Energy and resource saving. Energy supply. Unconventional and renewable power sources". Since 2000 more than 3500 people from several dozens of Russia's higher educational establishments have taken part in these youth events, organized by UrFU, 13 collections of students and post-graduates' works in this sphere have been published. Issued in December 2013 the collection is the fourteenth in this list [11].

Scientific-methodological approaches to forming fuel-energetic balance of the region have been worked through, main principles of economic activity energy analysis have been based, methodological recommendations for developing regional energy saving programmes have been worked out at the department. During recent years the work with the participation of specialists from Great Britain, Germany, France, Netherlands, Czech Republic on a wide scope of issues connected with energy efficient development of countries, regions and municipal units has activated. 


\section{President's programme for professional development of engineering staff and masters' training}

Since 2012, the department has been taking part in realizing President's programme for professional development of engineering staff planned for 20122014, having won in the contest held by the RF Ministry of education and science in the programme "Energy saving, raising energy efficiency and resource saving in industry". In November-December 201240 specialists of industrial enterprises and specialized organisations of Ural Federal District completed training following this programme. In 2013, 50 specialists of a number of enterprises and organisations of Sverdlovsk and Chelyabinsk regions were taught [12]. In 2014, this work will continue.

In 2012 masters' training started jointly with the department "Atomic power stations and renewable energy sources" following the programme "Power installations, power plants and complexes on the base of unconventional and renewable power sources" with deep studying of energy saving and raising energy efficiency. Taking into account this experience for the first time in Russia UrFU educational standard was developed "Energy saving and raising energy efficiency in industry and budget sphere", approved by Academic Board in December 2012, which is a base for developing and realizing main educational programmes of training highly qualified staff possessing master's degrees for various $\mathrm{RF}$ economy branches in this direction $[13,14]$.

\section{Conclusions}

Thus, on the Sverdlovsk oblast and Ural region territory a complex approach to creating and constant improving the system of training specialists in energy saving has been realized and is developing. This work is in keeping with the efforts made in our country for reducing energy consumption of Russian and regional economy, guaranteeing rational and ecologically responsible energy and power resources usage in accordance with the Federal law issued on November 23, 2009 № 261-FZ “About energy saving and raising energy efficiency...” on the way to creating a modern energy efficient society.

Positive experience of realizing multicomponent educational system in the field of energy saving shows that taking into account results of educational activity in this direction it was possible to reduce regional energy consumption growth rate keeping stable economy growth dynamics $[15,16]$.

\section{References}

[1] Danilov, N.I., Timofeeva, U.N. \& Shchelokov, Y.M., Energy saving for beginners, Uralenergo-Press: Ekaterinburg, 80 p., 2004; 2nd edition, 100 p., 2005. 
[2] Danilov, N.I., Evplanov, A.I., Mikhailov, V.U. \& Shchelokov, Y.M., Energy saving. Introduction in the issue: study guide, EH "Socrat": Ekaterinburg, 208 p., 2001.

[3] Danilov, N.I., Timofeeva, U.N., Usolcev, A.P., Shchelokov, Y.M. \& Baldin V.U., Using resources and energy: study guide, Ural IDGC; AMB publishing house: Ekaterinburg, 184 p., 2010; Ekaterinburg city administration; AMB publishing house: Ekaterinburg, 184 p., 2011.

[4] Danilov, N.I., Baldin, V.Ju. \& Rossel, E.E., System der Schulung und Qualifizierung von Fach-leuten für Energieeinsparung: Regionale Erfahrungen. Euro-Eco. Hannover 2013. Ökologische, Technologische und Rechtliche Aspekte der Lebensversorgung: Das Internationale Symposium (28-29 November 2013), Europäischen Wissenschaftlichen Gesellschaft: Hannover, S. 32-33, 2013.

[5] Danilov, N.I. \& Shchelokov, Y.M., Energy saving fundamentals: textbook, Sverdlovsk region state institution "Energy saving institute": Ekaterinburg, 526 p., 2008.

[6] Danilov, N.I. \& Shchelokov, Y.M., Energy saving fundamentals: textbook, PH “Avtograf”: Ekaterinburg, 528 p., 2009; 550 p., 2010; 592 p., 2011.

[7] Algorithm of forming energy saving regional programmes, IFC consultative programme in Europe and Central Asia, IFC: Washington, 64 p., 2010.

[8] Energetics and sustainable development. 2009: Report on human potential development in the Russian Federation, UN development programmes (UNDP), ed. S.N. Bobylev, Design-project "Samolyot", 180 p., 2010.

[9] Shchelokov, Y.M. \& Danilov, N.I., Energy saving in budget sphere: reference book, UrFU, SRO NP "Union "Energy efficiency", Ural Energy service company: Ekaterinburg, 237 p., 2012.

[10] Danilov, N.I., Baldin, V.U., Begalov, V.A., Velkin, V.I., Proskuryakov, V.S. \& Shchelokov, Y.M., Organising energy saving work in Sverdlovsk region municipal entities: electronic textbook, Ekaterinburg, URL: http://www.midural.ru/midural-new/training/textbook/

[11] Energy and resource saving. Energy supply. Unconventional and renewable power sources: Collection of materials of all-Russian students' academic olympics, scientific-practical conferences with international participation exhibitions of scientific-technical creative work of students, post-graduates and young scientists, 17-20 December 2013, Scientific ed. V.U. Baldin, I.S. Seleznyova, ed. prof., PhD N.I. Danilov, UrFU: Ekaterinburg, 446 p., 2013.

[12] Hudyakova, G.I., Bunjkova, E.A., Danilov, N.I. \& Silin, V.E., Realising President's programme for professional development of engineering staff "Energy saving, raising energy efficiency and resource saving in industry" in 2012-2013. Energy and resource saving. Energy supply. Unconventional and renewable power sources: Collection of materials of all-Russian students' academic olympics, scientific-practical conferences with international participation exhibitions of scientific-technical creative 
work of students, post-graduates and young scientists, 17-20 December 2013, UrFU: Ekaterinburg, pp. 229-231, 2013.

[13] Baldin, V.U., Danilov, N.I., Department "Energy saving” UrFU: masters' training has started. Energy saving and raising energy efficiency in budget sphere: Collection of materials of interuniver-sity conference, 15 November 2012, UrFU: Ekaterinburg, pp. 31-36, 2012.

[14] Velkin, V.I., Shcheklein, S.E. \& Danilov, N.I., Accelerated - doesn't mean cut. Big Ural, 3 (December), pp. 34-35, 2012.

[15] Danilov, N.I. \& Shchelokov, Y.M., Energy saving. Theory and practice: vol. 1. Theoretical bases of energy saving: study guide, ed. N.I. Danilov, UrFU: Ekaterinburg, 296 p., 2013.

[16] Danilov, N.I., Baldin, V.U. \& Shchelokov, Y.M., Energy saving. Theory and practice: vol. 2. Practice of energy efficiency management: study guide, ed. N.I. Danilov, UrFU: Ekaterinburg, 348 p., 2013. 